\title{
Nature of the immune response in coho salmon Oncorhynchus kisutch following vaccination with Vibrio ordalii lipopolysaccharide by two different routes
}

\author{
M. I. Velji ${ }^{1}$, T. P. T. Evelyn ${ }^{2}$, L. J. Albright ${ }^{1}$ \\ 1 mepartment of Biological Sciences, Simon Fraser University, Burnaby, British Columbia, Canada V5A 1S6 \\ ${ }^{2}$ Department of Fisheries and Oceans, Biological Sciences Branch, Pacific Biological Station, Nanaimo, British Columbia, \\ Canada V9R 5K6
}

\begin{abstract}
A3STRACT: The question as to whether immersion (=IMM) vaccination stimulates an immune nesponse similar to that yielded by vaccination via the intraperitoneal (=IP) route was examined using Vbrio ordalii (Vo) lipopolysaccharide as immunogen and coho salmon Oncorhynchus kisutch as test fish. The experimental approach was to determine if the partially purified immunoglobulins in the plasma and mucus from coho salmon vaccinated by each of the above methods were protective to naive coho recipients. Results indicated that the plasma immunoglobulins from IP- and IMM-vaccinated coho Frotected the naive coho recipients against challenge with live Vo cells. Protection was due to Vo-specific antibodies because the protection could be removed from the transferred material by absorption with Vo cells but not with cells of a serologically unrelated fish pathogen (Renibacterium salmoninarum). No piotection was transferred with material concentrated from mucus of donors that were IP- or IMMvaccinated. Overall, our results indicate that both IP and IMM methods of vaccination yield a humoral is,stemic) response and that this response is probably the important protective response following vaccination or following natural challenges in the field.
\end{abstract}

\section{INTRODUCTION}

The intraperitoneal (=IP) vaccination of salmonids with Vibro anguillarum (=Va) bacterins elicits a humoral inmune response resulting in protection against withriosis (Harrell et al. 1975, Groberg 1982). This was clemonstrated by passively transferring serum from IP-immized fish to naive fish, the latter then showing protective immunity upon challenge with Va. There wasi a protection in the recipient fish when the immune:sen m was absorbed with Va cells prior to the passive transfer, indicating the specificity of the antibody transfierred (Harrell et al. 1976). Local immunity also appeared to occur in rainbow trout Oncorhynchus mykiss vacinated with Va bacterins by the IP route because custaneous mucus from such fish displayed anti-Va ativity. However, the activity in the mucus occurred a much lower level than that in the serum and it was only observed when the Va bacterin contained adjuant (Harrell et al. 1976).
Bath or immersion (=IMM) vaccination is an effective and convenient way of immunizing fish against several bacterial fish pathogens. However, very little is known about the nature of the immune response(s) elicited (Tatner \& Horne 1986), and there is considerable uncertainty as to whether it stimulates the same immune response(s) as that (those) elicited by the IP route. IMM-immunized rainbow trout showed no antiVa activity in cutaneous mucus (Tatner \& Horne 1986) even though studies indicate that lymphocytes capable of producing anti-Va antibodies following IMM vaccination occur in the integument of rainbow trout (St. Louis-Cormier et al. 1984, Pelleteiro \& Richards 1988, Magor \& Cone 1989). On the other hand, IMM-vaccinated salmonids sometimes show a humoral immune response to Va vaccines (compare, for example, Croy \& Amend 1977, Sasaki \& Ghoda 1983, Aoki et al. 1984, Kawano et al. 1984, Sakai et al. 1984, Ward et al. 1985, Tatner \& Horne 1986, Thuvander et al. 1987, Thorburn \& Jansson 1988, Thorburn et al. 1989). When the 
response was positive, it was generally weak. 'High' levels of humoral antibodies, detectable by the enzyme-linked immunosorbent assay, have only been reported once in IMM-vaccinated fish but even in this case the proportion of fish sero-positive by the IMM method was considerably lower than that found for IPvaccinated fish (Thorburn et al. 1989). Attempts, using the passive transfer approach, to determine whether humoral immunity occurs in salmonids following IMM vaccination have yielded contradictory results. Viele et al. (1980) were successful in transferring immunity to naive rainbow trout with plasma from rainbow trout IMM-vaccinated with Va. On the other hand, Aoki et al. (1984) found the opposite using ayu Plecoglossus altivelis.

This study was conducted to determine if vaccination by the IMM route elicits an immune response similar to that induced via the IP route. Would, for example, the serum and mucus from fish vaccinated by each of these routes contain protective antibodies? We examined this question by attempting to transfer immunity to naive coho salmon with plasma and mucus preparations from coho donors immunized by the IP or IMM route with Vibrio ordalii (Vo) lipopolysaccharide (= LPS). Vo, like the better known $\mathrm{Va}$, produces a highly immunogenic LPS, which, in our experience (Velji et al. 1990). elicited strong anti-Vo protection in the absence of detectable serum agglutinins.

\section{MATERIALS AND METHODS}

Bacterial strains. The $V_{0}$ isolate (74/48) used for challenging the recipient coho salmon Oncorhynchus kisutch was originally isolated from a sockeye salmon Oncorhynchus nerka that had died of vibriosis (Evelyn $\&$ Ketcheson 1980). The isolate was also used for the preparation of cell-wall LPS (the antigen used for vaccinating fish in the present study) (Velji. et al. 1990), and for the absorption of coho plasma and mucus and of rabbit anti-Vo serum (used as reference reagent). Vo cells were grown either on tryptic soy agar (Difco) (=TSA), or in brain heart infusion broth (Difco) (=BHIB), both of which were supplemented with $1 \%$ $\mathrm{NaCl}$. The Renibacterium salmoninarum (=Rs) isolate (isolate 384) used for the absorption of the various plasma, mucus, and serum preparations, was isolated from a juvenile chinook salmon Oncorhynchus tshawytscha (Evelyn et al. 1986) and was grown on KDM2 medium (Evelyn 1977). Prior to their use for absorbing the plasma, serum, and mucus preparations, Vo and Rs cells were heat-killed $\left(70^{\circ} \mathrm{C}\right.$ for $\left.30 \mathrm{~min}\right)$ and salinewashed.

Experimental animals. The juvenile coho salmon used in this study were from a local stock (Big Qua- licum River) and were reared in well water at the Department of Fisheries and Oceans Rosewall Creek facility. The fish were transported to the laboratory at the Pacific Biological Station at least $10 \mathrm{~d}$ prior to use and were held in 8001 tanks, supplied with flowing dechlorinated city water. The fish were gradually acclimatized to a temperature of $13 \pm 1^{\circ} \mathrm{C}$. Donor salmon were from the 1988 hatch; recipient coho were from the 1989 hatch

Active immunization of donor coho. Coho salmon (average weight $80 \mathrm{~g}$ ) used as source of plasma and mucus were divided into 3 groups of 17 fish each. The first group served as unvaccinated controls; the second was IMM-immunized for $15 \mathrm{~min}$ in $2 \mathrm{I}$ of aerated fishculture water containing $5 \mu \mathrm{g}$ of $\mathrm{Vo}$ LPS $\mathrm{ml}^{-1}$; the third was IP-immunized with 1 kg of Vo LPS fish ${ }^{-1}$. Vo LPS was quantitated by the chromogenic limulus amoebocyte lysate method (Whitaker M. A., Bio-Products, Walkerville, MD). Each group was maintained separately for $21 \mathrm{~d}$ post vaccination in tanks supplied with flowing dechlorinated city water at $13 \pm 1{ }^{\circ} \mathrm{C}$. After this time, the fish were anesthetized with 2-phenoxy-ethanol (1:7000) and the cutaneous mucus was collected by a combination of flushing (with $0.15 \mathrm{M}, \mathrm{pH} 7.4$ phasphate buffered saline $=$ PBS) and suction. This method proved to be easier for harvesting mucus than the other methods described to date (Harrell et al. 1976, Cipriano 1986, Lobb 1987). Immediately after mucus collection, blood samples were obtained from the severed caudal peduncle in heparinized Caraway tubes. The blocd was centrifuged and the plasma harvested. Mucus and plasma samples were pooled separately, according to treatment group.

Rabbit anti-Vo serum production. Antiserum against Vo was produced by intravenous injection of a New Zealand white female rabbit with boiled Vo cells (presumably containing the heat stable LPS antigen) using the immunization schedule of Toranzo et al. (1987) with slight modifications. Vo cells were grown in BHIB, supplemented with $1 \% \mathrm{NaCl}$, for $48 \mathrm{~h}$ at $21^{\circ} \mathrm{C}$ and then pelleted by centrifugation. Cells were washed twice with PBS and then suspended in PBS to an optical density of 6.0 at $540 \mathrm{~nm}$. They were then boiled for $1 \mathrm{~h}$. The initial immunization schedule was similar to that of Toranzo et al. (1987). The rabbit was allowed to rest for 2 wk after which it was boosted with the antigen. The blood was collected $1 \mathrm{wk}$ later from the marginal ear vein and was allowed to clot. The resulting anti-Vo serum was used as described in the ensuing sections.

Preparation of materials to be passively transferred. Coho mucus:PBS washings were spun in a clinical centrifuge at $3000 \times g$ for 10 min to pellet any particu. late material. Some $250 \mathrm{ml}$ of dilute mucus from each treatment group were then concentrated by positive pressure in an ultrafiltration cell equipped with a 
YM100 filter (Amicon Corp., Danvers, MA). Coho mucus and plasma were then each treated with $50 \%$ ammonium sulphate ( $w / v$, final concentration) to precipitate any immunoglobulins present. The precipitate was redissolved in PBS and dialyzed against PBS Dilute mucus preparations were then concentrated to the stage where they contained ca $0.8 \mathrm{mg}$ protein per $\mathrm{ml}$ (based on absorbance at $280 \mathrm{~nm}$; see Scopes 1982). Plasma preparations were adjusted with PBS to contain approximately the same concentration of protein (1.0 $\mathrm{mg} \mathrm{ml}^{-1}$ ). Mucus and plasma preparations were then filter-sterilized using a $0.22 \mu \mathrm{m}$ pore size Millipore membrane and stored at $-20^{\circ} \mathrm{C}$ until used. Rabbit antiserum was treated with ammonium sulphate to a final concentration of $45 \%(\mathrm{w} / \mathrm{v})$, and the resulting precipitate was dissolved in PBS and then dialyzed against PBS. This was followed by dialysis against $0.075 \mathrm{M}$ PBS (half strength PBS) and loading on a DEAE Sephacel ion exchange column that had previously been equilibrated with the same buffer. The protein fraction (monitored at $280 \mathrm{~nm}$ ) that ran through the column in the void volume represented the immunoglobulin and was collected (Clark \& Adams 1977). Based on absorbance at $280 \mathrm{~nm}$, the protein content of the fraction was $0.54 \mathrm{mg} \mathrm{ml}^{-1}$ (Scopes 1982). The immuno-globulin preparation was diluted $1 / 10$ with PBS prior to absorption

Absorption of coho mucus, coho plasma, and rabbit serum. The immunoglobulin-enriched protein fractions obtained from vaccinated and unvaccinated coho and from the vaccinated rabbit were each divided into 3 equal aliquots. One aliquot of each was left untreated, i.e. unabsorbed. The second and third aliquots were absorbed 3 times with $\mathrm{Vo}$ and Rs cells, respectively. Prior to their use, Vo and Rs cells were suspended separately in PBS to a calculated optical density of 11.0 at $540 \mathrm{~nm}$. The cells were then pelleted by centrifugation and the supernatant was replaced with an equal volume of the preparation to be absorbed. The pelleted cells were resuspended by vortexing and the mixtures were incubated at $15^{\circ} \mathrm{C}$ for $7 \mathrm{~h}$ with occasional mixing. After absorption, cells were removed by centrifugation and supernatants were absorbed 2 more times. Absorbed preparations were stored at $4{ }^{\circ} \mathrm{C}$ until used.

Passive transfer. Juvenile coho (average weight $5.2 \mathrm{~g}$ ) were anesthetized as already described and then injected IP with $0.1 \mathrm{ml}$ of one or the other of the above absorbed or unabsorbed preparations. Eighteen coho were used for each preparation, and fish receiving the various preparations were held in separate $35 \mathrm{l}$ tanks supplied with dechlorinated city water at $13 \pm 1{ }^{\circ} \mathrm{C}$. Each fish was challenged IP 5 h later with $0.1 \mathrm{ml}$ of PBS containing $7.7 \times 10^{5}$ live Vo cells. Resulting deaths in the challenged fish were monitored for $14 \mathrm{~d}$, by which time deaths appeared to have ceased. Kidney samples from $10 \%$ of the dead fish were plated on TSA supplemented with $1 \% \mathrm{NaCl}$ to verify the cause of death. Identification of $V o$ growth on the plates was accomplished using Vo-specific rabbit antiserum (Microtek, Sidney, BC) in a slide agglutination test.

Statistical analysis. Mortalities among the various treatment groups were compared using the log-likelihood ratio or G-test to determine whether they were significantly different (Sokal \& Rohlf 1981). We were particularly interested in determining whether plasma or mucus preparations from vaccinated fish yielded survival superior to that from unvaccinated fish or to that of fish receiving saline. We were also interested in determining whether plasma or mucus preparations from IMM- and IP-vaccinated fish yielded different survivals and whether absorption of the preparations with Vo or Rs cells affected the survivals.

\section{RESULTS AND DISCUSSION}

When plasma was the preparation passively transferred, mortality levels in the Vo-challenged recipient fish depended on whether the fish donating the plasma had been immunized and on whether homologous antigen had been used to absorb the transferred plasma preparation $(\mathrm{p}<0.01)$ (Table 1 ). Fish receiving material from IP- or IMM-vaccinated donors survived significantly better $(p<0.01)$ than those receiving material from unvaccinated donors or than those receiving only saline. This clearly indicates that vaccination by both methods results in the production of humoral factors (almost certainly immunoglobulins, as discussed later) capable of conferring protection against Vo. There did not appear to be any differences in mortality when IP and IMM methods of vaccination were compared $(p>0.05)$. In active immunization, one would have expected vaccination by the IP route to yield stronger protection than that obtained via the IMM route (Evelyn 1984). However, with the passive immunization approach used, we were not measuring the relative strengths of active immunity produced by the 2 methods. We measured only the fact that, at $21 \mathrm{~d}$ post vaccination, the levels of the protective factors in the plasma of fish vaccinated by each method were adequate to protect against the challenge dose used.

The results listed in Table 1 also show that the protective effect of plasma preparations from immunized donor coho could be removed by absorbing the preparation with the homologous antigen (Vo cells) $(p<0.01)$ but not with a serologically unrelated antigen (Rs cells) $(p>0.05)$. The protection conferred by the plasma preparations was therefore Vo-specific. Protection obtained with serum preparations derived from the Vo-vaccinated rabbit also showed a similar specificity: 
Table 1. Oncorhynchus kisutch. Passive immunization with plasma preparations from donor coho immunized with $V$. ordalii (Vo) lipopolysaccharide (LPS): effect of vaccination method and of absorbing the plasma preparations with Vo and $R$. salmoninarum (Rs) cells ${ }^{\mathrm{a}}$

\begin{tabular}{|c|c|c|}
\hline $\begin{array}{l}\text { Preparation } \\
\text { transferred }\end{array}$ & $\begin{array}{c}\text { Immunization method } \\
\text { of donor }\end{array}$ & $\begin{array}{l}\text { No. fish dead/ } \\
\text { no. challenged }\end{array}$ \\
\hline $\begin{array}{l}\text { Coho plasma } \\
\text { (non-absorbed) }\end{array}$ & $\begin{array}{l}\text { None (control) } \\
\text { IMM } \\
\text { IP }\end{array}$ & $\begin{array}{r}18 / 18 \\
1 / 18 \\
3 / 18\end{array}$ \\
\hline $\begin{array}{l}\text { Coho plasma } \\
\text { (Vo-absorbed) }\end{array}$ & $\begin{array}{l}\text { None (control) } \\
\text { IMMI } \\
\text { IP }\end{array}$ & $\begin{array}{l}18 / 18 \\
18 / 18 \\
18 / 18\end{array}$ \\
\hline $\begin{array}{l}\text { Coho plasma } \\
\text { (Rs-absorbed) }\end{array}$ & $\begin{array}{l}\text { None (control) } \\
\text { IMM } \\
\text { IP }\end{array}$ & $\begin{array}{r}16 / 18 \\
5 / 18 \\
1 / 18\end{array}$ \\
\hline $\begin{array}{l}\text { Rabbit serum }{ }^{d} \\
\text { (non-absorbed) }\end{array}$ & IV & $0 / 18$ \\
\hline $\begin{array}{l}\text { Rabbit serum } \\
\text { (Vo-absorbed) }\end{array}$ & IV & $18 / 18$ \\
\hline $\begin{array}{l}\text { Rabbit serum } \\
\text { (Rs-absorbed) }\end{array}$ & IV & $0 / 18$ \\
\hline $\begin{array}{l}\text { Phosphate buffered } \\
\text { saline (PBS) }\end{array}$ & None & $15 / 18$ \\
\hline \multicolumn{3}{|c|}{$\begin{array}{l}\text { " Recipient fish averaged } 5.2 \mathrm{~g} \text { and were held at } 13 \pm 1{ }^{\circ} \mathrm{C} \text {; they were challenged intraperitoneally with } 7.7 \times 10^{5} \text { live Vo cells } \\
5 \mathrm{~h} \text { after receiving the test preparation; ensuing deaths were monitored for } 14 \mathrm{~d} \\
\text { b Donor coho averaged } 80 \mathrm{~g} \text { and were vaccinated by a } 15 \mathrm{~min} \text { immersion in water containing } 5 \mu \mathrm{gg} \text { of Vo LPS } \mathrm{ml}^{-1}(=\mathrm{IMM} \\
\text { method), by intraperitoneal injection of } 1 \mu \mathrm{g} \text { Vo LPS fish }{ }^{-1} \text { (IP method), or by intraperitoneal injection of PBS (controls) } \\
{ }^{c} \text { Groups with } 0 \text { to } 5 \text { fish dead are significantly different from groups with } 15 \text { to } 18 \text { fish dead }(\mathrm{p}<0.01 \text { ). Groups with } 0 \text { to } 5 \text { fish } \\
\text { dead are not significantly different from each other ( } \mathrm{p}>0.05 \text { ). Groups with } 15 \text { to } 18 \text { fish dead are not significantly different } \\
\text { from each other (p }>0.05 \text { ) } \\
\text { d Rabbit anti-Vo serum preparations were used for comparative purposes; for details of their preparation consult text }\end{array}$} \\
\hline
\end{tabular}

protection could be abrogated by absorption with Vo cells $(p<0.01)$ but not with cells of a heterologous pathogen (Rs) $(p>0.05)$. Taking into account the specificity of the protective factor, the fact that it was induced by vaccination, and the fact that it was precipitable with 45 to $50 \%$ ammonium sulphate, it seems likely that the factor was immunoglobulin.

The foregoing results for the IP-vaccinated coho are consistent with the results obtained for Va by Harrell et a. (1975) and Groberg (1982) who used serum from IPvaccinated rainbow trout and coho, respectively, to protect naive recipient fish against challenge with $\mathrm{Va}$ a protection that was shown to be specific (Harrell et al. 1975). Our results with IMM-vaccinated coho also agree with the findings of Viele et al. (1980) for rainbow trout that had been IMM-vaccinated with Va bacterins: serum from such fish protected naive rainbow trout recipients against $V$ a. In contrast, Aoki et al. (1984) reported that serum from ayu IMM-vaccinated with Va LPS was not protective for naive ayu recipients.

No Vo agglutinin titers were detected in the plasma samples from any of the coho, vaccinated or otherwise, in the present experiment (data not shown). The lack of detectable agglutinins in the vaccinated fish was probably due to the inherent insensitivity of the agglutination technique and the small amounts of antigen administered in our experiments. Other workers, using higher levels of antigen, have certainly observed humoral agglutinins in fish vaccinated by the IP route with Va bacterins (Harrell et al. 1976. Aoki et al. 1984) or with Va LPS (Salati et al. 1989). The agglutinin titers were highest when adjuvant was present in the vaccine (Harrell et al. 1976). The lack of detectable agglutinins observed in our experiments is more in line with what has been reported in the literature for fish vaccinated against $\mathrm{Va}$ by the IMM method: such fish contained low to no detectable humoral agglutinins (Aoki et al. 1984. Tatner \& Horne 1986) or anti-Va antibodies (Thorburn \& Jansson 1988); further, when IMMinduced humoral antibodies were detected, they occurred at lower levels and more sporadically than in IPvaccinated fish (Thorburn et al. 1989) and they occurred in highest titers only when the time of immersion in the vaccine was prolonged (Sasaki \& Ghoda 1983). It seems, therefore, that both IP and IMM methods of 
vaccination elicit the production of humoral antibodies in fish but that the titers of these antibodies are related to the amount of antigen that enters the fish to stimulate the response. With IMM vaccination, the amount of antigen entering the fish is normally less than that by the IP route and the degree of stimulation of the immune system in IMM-vaccinated fish would be correspondingly less intense (Zapata et al. 1987).

Mucus preparations from coho vaccinated by the IP and IMM routes did not prove protective $(p>0.05)$ for naive coho recipients (Table 2) and contained no detectable anti-Vo agglutinins (data not shown). This lack of any evidence of protective immunoglobulins in the mucus was not particularly surprising. In their studies with IP-vaccinated rainbow trout, Harrell et al. (1976) were only able to demonstrate the presence of mucous antibodies when adjuvant-containing Va vaccines were used and only in fish with unusually high humoral anti-Va titers $(>131,072)$. Further, although Tatner \& Horne (1986) were able to detect anti-Va and anti-Vo agglutinins in the serum of rainbow trout IMMvaccinated against $\mathrm{Va}$ and $\mathrm{Vo}$, they were unable to do so with mucus.

Our negative results with coho mucus may have been a function of the amount of Vo antigen used in our studies. Or, perhaps the immunoglobulin-secreting cells that have been reported as occurring in the salmonid integument (St. Louis-Cormier et al. 1984, Pelleteiro \& Richards 1988, Magor \& Cone 1989) require repeated dosing to induce them to secrete protective titers of antibody. If so, the cutaneous antibody secreting system in coho must be far less easily stimulated

Table 2. Oncorhynchus kisutch. Passive immunization with mucus preparations from donor coho immunized with $V$. ordalii (Vo) lipopolysaccharide (LPS): effect of vaccination method and of absorbing the mucus preparations with Vo and $R$. salmoninarum (Rs) cells ${ }^{\mathrm{a}}$

\begin{tabular}{|llc|}
$\begin{array}{l}\text { Preparation } \\
\text { transferred }\end{array}$ & $\begin{array}{c}\text { Immunization } \\
\text { method of donor }\end{array}$ & $\begin{array}{c}\text { No. fish dead) } \\
\text { no. challenged }\end{array}$ \\
\hline Coho mucus & None (control) & $15 / 18$ \\
(non-absorbed) & IMM & $18 / 18$ \\
& IP & $17 / 18$ \\
Coho mucus & None (control) & $18 / 18$ \\
(Vo-absorbed) & IMM & $16 / 18$ \\
& IP & $18 / 18$ \\
Coho mucus & None (control) & $18 / 18$ \\
(Rs-absorbed) & IMM & $14 / 18$ \\
& IP & $14 / 18$ \\
Phosphate buffered & & $15 / 18$ \\
saline (PBS) & - & \\
a. b See details under Table 1 & \\
${ }^{c}$ None of the groups showed deaths that were significantly \\
different from each other
\end{tabular}

than that in channel catfish (Ourth 1980, Lobb 1987). Whatever the explanation, we conclude that mucusmediated immunity to $\mathrm{Vo}$ in coho is not likely to be nearly as important as systemically (humorally) mediated immunity, particularly under challenge conditions experienced in nature or in netpens. The basis of this conclusion is that doses of Vo LPS as high as $1 \mu \mathrm{g}$, administered by IP injection, failed to produce factors in coho mucus protective against $V_{0}$. This amount of LPS is equivalent to ca $5 \times 10^{6}$ Vo cells (Velji unpubl.) a dose of Vo cells that in our laboratory has regularly resulted in $100 \%$ mortality when injected into juvenile coho salmon and that is far in excess of the number of living Vo cells needed to induce measurable anti-Vo immunity in coho by bath exposure (Velji et al. 1990). Whether the relative unimportance of the cutaneous immune system in coho for Vo holds true for other salmonids and fish pathogens remains to be determined.

Acknowledgements. We thank J. E. Ketcheson, L. ProsperiPorta, and L. Needham for technical assistance, Dr $T$ Beacham for advice on the statistical analyses, and $Y$ Jiwani for reading the manuscript. This research was partially supported by an operating grant to L.J.A. from the National Sciences and Engineering Research Council of Canada.

\section{LITERATURE CITED}

Aoki, T., Sakai, M., Takahashi, S. (1984). Protective immunity in ayu (Plecoglossus altivelis), vaccinated by immersion with Vibrio anguillarum. Fish Pathol. 19: 181-185

Cipriano, R. C. (1986). Immunodetection of antibodies in the mucus of rainbow trout infected with or immunized against the furunculosis agent Aeromonas salmonicida. Microbios. Lett. 32: 105-112

Clark, M. F., Adams, A. N. (1977). Characteristics of the microplate method enzyme-linked immunosorbent assay for the detection of plant viruses. J. gen. Virol. 34:475-483

Croy, T R., Amend, D. F. (1977). Immunization of sockeye salmon (Oncorhynchus nerka) against vibriosis using the hyperlosmotic infiltration technique. Aquaculture 12: 317-325

Evelyn, T P. T (1977). An improved growth medium for the kidney disease bacterium and some notes on using the medium. Bull. Off. int. Epiz. 87. 511-513

Evelyn, T P. T. (1984). Immunization against pathogenic vibrios. In: de Kinkelin, P., Michel, C. (eds.) Symposium on fish vaccination, Office International des Epizooties (O.I.E.) Fish Diseases Commission, Paris, p. 121-150

Evelyn, T P. T., Ketcheson, J. E. (1980). Laboratory and field observations on antivibriosis vaccines. In: Ahne, W (ed.) Fish diseases. Third COPRAQ session. Springer-Verlag, Berlin, p. 45-54

Evelyn, T P. T., Prosperi-Porta, L., Ketcheson, J. E. (1986). Experimental intra-ovum infection of salmonid eggs with Renibacterium salmoninarum and vertical transmission of the pathogen with such eggs despite their treatment with erythromycin. Dis. aquat. Org. 1: 197-202

Groberg, W. J., Jr (1982). Infection and the immune response induced by Vibrio anguillarum in juvenile coho salmon 
(Oncorhynchus kisutch). Ph.D. Thesis, Oregon State University, Corvallis, Oregon

Harrell, L. W., Etlinger, H. M., Hodgins, H. O. (1975). Humoral factors important in resistance of salmonid fish to bacterial disease. I. Serum antibody protection of rainbow trout (Salmo gairdnen) against vibriosis. Aquaculture 6: 211-219

Harrell, L. W., Etlinger, H. M., Hodgins. H. O. (1976). Humoral factors important in resistance of salmonid fish to bacterial disease. II. Anti-Vibrio anguillarum activity in mucus and observations on complement. Aquaculture 7: 363-370

Kawano, K., Aoki, T., Kitao, T. (1984). Duration of protection against vibriosis in ayu (Plecoglossus altivelis) vaccinated by immersion and oral administration with Vibrio anguillarum. Bull. Jap. Soc. scient. Fish. 50: 771-774

Lobb, J. L. (1987). Secretory immunity induced in catfish, Ictalurus punctatus, following bath immunization. Devl. comp. Immun., N.Y. 11: 727-738

Magor, B. G., Cone, D. K. (1989). Immunocytochemical evidence of $\mathrm{B}$-iymphocytes, and epithelial cells that express surface immunoglobulin, in rainbow trout (Salmo gairdneri) epidermis. Devl. comp. Immunol., N.Y 13: 361

Ourth, D. D. (1980). Secretory IgM, lysozyme and lymphocytes in the skin mucus of the channel catfish (Ictalurus punctatus). Devl. comp. Immun., N.Y. 4: 65-74

Pelleteiro, M. C., Richards, R. H. (1988). Immunocytochemical studies on immunoglobulin-containing cells in the epidermis of rainbow trout Salmo gairdneri Richardson: influence of bath vaccination. J. Fish Biol. 32: 845-858

Sakai, M., Aoki, T., Rohovec, J. S., Fryer, J. L. (1984). Comparisons of the cellular immune response of fish vaccinated by immersion and injection of Vibrio anguillarum. Bull. Jap. Soc. scient. Fish. 50: 1187-1192

Salati, F., Watanabe, K., Kawai, K., Kusuda, R. (1989). Immune response of ayu against Vibrio anguillarum. Bull. Jap. Soc. scient. Fish. 55: 45 49

Sasaki, T., Ghoda, A. (1983). Comparison of different vaccine regimes for vibriosis vaccines. In: Anderson, D. P., Dorson, M., Dubourget, P. H. (eds.) Antigens of fish pathogens. Symposium International de Talloires, Collection Fondation Marcel Merieux, France, p. 268

St. Louis-Cormier, E. A., Osterland, C. K., Anderson, D. P. (1984). Evidence for a cutaneous secretory immune system in rainbow trout (Salmo gairdnern). Devl. comp. Immunol N.Y. 8: 71-80

Editorial responsibility: Managing Editor
Scopes, R. K. (1982). Protein purification. Springer-Verlag, New York

Sokal, R. S., Rohlf, F. J. (1981). Biometry. The principles and practice of statistics in biological research, 2nd edn. W. H. Freeman and Company, New York

Tatner, M. F., Horne, M. T (1986). Correlation of immune assays with protection in rainbow trout, Salmo gairdneri, immersed in Vibrio bacterins. J. appl. Ichthyol. 3: 130-139

Thorburn, M. A., Jansson, E. L. K. (1988). The effects of booster vaccination and fish size on survival and antibody production following vibrio infection of bath-vaccinated rainbow trout, Salmo gairdneri. Aquaculture 71: 285-291

Thorburn, M. A., Jansson, E., Thuvander, A. (1989). Vibriosis vaccination of rainbow trout Salmo gairdneri at varying temperatures and seasons. II. Effect on antibody production in five Swedish field trials. Dis. aquat. Org. $6: 27-32$

Thuvander, A., Hongslo, T., Jansson, E., Sundquist, B. (1987) Duration of protective immunity and antibody titres measured by ELISA after vaccination of rainhow trout, Salmo gairdneri Richardson, against vibriosis. J. Fish Dis. 10 $479-486$

Toranzo, A. E., Baya, A. M., Roberson, B. S., Barja, J. L., Grimes, D. J., Hetrick, F. M. (1987). Specificity of slide agglutination test for detecting bacterial fish pathogens. Aquaculture 61: 81-97

Velji, M. I., Albright, L. J., Evelyn, T. P. T. (1990). Protective immunity in juvenile coho salmon (Oncorhynchus kisutch) following immunization with Vibrio ordali lipopolysaccharide or from exposure to live $V$. ordalii cells. Dis. aquat Org. 9: 25-29

Viele, D., Kerstetter, T H., Sullivan, J. (1980). Adoptive transfer of immunity against Vibrio anguillarum in rainbow trout, Salmo gairdneri Richardson, vaccinated by the immersion method. J. Fish Biol. 17: 379-386

Ward, P. D., Tatner, M. F., Horne, M. T. (1985). Factors affecting the efficacy of vaccines against vibriosis caused by Vibrio anguillarum. In: Manning, M. J., Tatner, M. F. (eds.) Fish immunology. Academic Press, London, p. $221-229$

Zapata, A. G., Torroba, M., Alvarez, F., Anderson, D. P., Dixon, O. W., Wisniewski, M. (1987). Electron microscopic examination of antigen uptake by salmonid gill cells after bath immunization with a bacterin. J. Fish Biol. 31 (Suppl. A): 209-201

Manuscript first received: February 12, 1991

Revised version accepted: May 30, 1991 